\title{
RITUAL IDER BUMI DI DESA KEMIREN, KECAMATAN GLAGAH, KABUPATEN BANYUWANGI
}

\begin{abstract}
Sulistyani ${ }^{1}$
Abstrct : Ritual Ider Bumi one of existing ceremony ritual society of Using Banyuwangi, as statement or expression thank goodness for blessing which have been accepted to the countryside security during one year. Society Using is original society Banyuwangi, (those who do not want to coexist with the society urban). Society Using in Kemiren village, its confidence embrace the Islam, but also still run the culture which inherit from its ancestor. Religion and cultural walk along, till able to form the ceremony ritual like that ceremony of ritual Ider Bumi executed in each feast day of Ramadan Idul Fitri.
\end{abstract}

Key word: Ritual, Ider Bumi, Using, Sinkretisme, Hegemony

Ritual Ider Bumi adalah sebuah ritual yang diselenggarakan masyarakat Using di Desa Kemiren Kecamatan Glagah Kabupaten Banyuwangi. Sebagai ungkapan rasa syukur atas keselamatan seluruh warga masyarakat lewat keamanan desa. Peristiwa ritual Ider Bumi ini selalu disambut oleh seluruh warga karena terkait dengan mitos yang diyakininya tentang Buyut Cili (danyang Desa Kemiren).

Kata ider bumi merupakan penggabungan dari dua kata yaitu ider dan bumi. Kedua kata tersebut masing-masing mempunyai arti dan makna tersendiri. Menurut Poerwadarmito (1939:33 dan 167) kata ider berarti berkeliling kemana-mana, dan kata bumi artinya jagat atau tempat berpijak. Dari arti kedua kata tersebut dapat dimengerti bahwa Ider Bumi dimaksudkan adalah kegiatan mengeliling tempat berpijak atau bumi.

Keyakinan seluruh warga Desa Kemiren tentang Buyut Cili dapat dikatakan percaya terhadap mitos, karena cerita tentang Buyut Cili tidak ada satupun data yang otentik dapat menguak cerita yang ada, sumber yang didapat berdasarkan keterangan secara lisan dari warga pendukungnya, tetapi masyarakat Kemiren sebagai penyangga budaya sangat meyakininya. Cerita tentang Buyut Cili diturunkan dari masyarat dahulu hingga sekarang secara lisan.

Batasan tentang mitos telah dipaparkan secara jelas oleh Endraswara (2003:193) bahwa mitos adalah cerita suci berbentuk simbolik yang mengi-

${ }^{1}$ Sulistyani adalah Dosen Jurusan Seni Tari Fakultas Seni Pertunjukan Institut Seni Indonesia Denpasar. 
sahkan serangkaian nyata dan imajiner menyangkut asal-usul dan perubahan-perubahan alam raya dan dunia, dewa-dewi, kekuatan-kekuatan atas kodrati, manusia, pahlawan, dan masyarakat. Ciri mitos adalah memiliki sifat suci atau sakral, karena terkait dengan tokoh yang sering dipuja. Mitos seringkali sulit dipahami kebenarannya, dan sering bersumber dari tempattempat sakral.

Peursen dalam Daeng (2000:81) juga memperjelas tetang fungsi mitos dalam masyarakat bahwa mitos yang berupa cerita yang mampu memberikan pedoman dan arah tertentu kepada sekelompok orang. Mitos juga mampu menyadarkan manusia akan kekuatan-kekuatan ajaib. Melalui mitos manusia dibantu untuk dapat menghayati daya-daya sebagai suatu kekuatan yang mempengaruhi dan menguasai alam.

Dari uraian ini mampu memberikan kejelasan tentang keadaan yang terjadi di Desa Kemiren, bahwa Buyut Cili mampu selalu hadir dalam kepercayaannya, mampu memberikan pedoman bagi seluruh warga untuk berbuat baik dan selalu ingat bahwa di luar mereka ada sesuatu kekuatan yang mampu mempengaruhinya.

Tempat yang disakralkan dijadikan sebagai objek atau sarana persembahan seperti sebuah makam Buyut Cili yang ditempatkan di atas segalanya oleh warga Desa Kemiren. Oleh karena itu segala peristiwa dikaitkan dengannya, terbukti dari kegiatan yang dilaksanakan warga selalu melibatkan persembahan sesaji untuk Buyut Cili lewat upacara slametan.

Upacara slametan merupakan ritual yang dilaksanakan oleh masyarakat di Jawa pada umumnya, dari masing-masing daerah mungkin saja berbeda istilah dan tata caranya, tetapi pada intinya sebuah slametan dimaksudkan untuk memohon keselamatan seluruh pelaksananya. Harapan masa depan yang lebih cemerlang, dan untuk mendapatkan ridha Tuhan. Mereka takut meninggalkan kegiatan ini karena sudah menjadi keyakinannya apabila meninggalkan tradisi ini dan melanggar tidak akan mendapat berkah.

Ritual-ritual yang terdapat di Banyuwangi pada umumnya melibatkan sajian seni pertunjukan, hal ini senada dengan penjelasan Kusmayati (2000:12) yang bertolak dari peristiwa ritual di Madura. Menurutnya upacara merupakan ungkapan kehendak bersama suatu masyarakat, yang diwujudkan melalui media gerak, suara serta rupa yang dibawakan sebagai sebuah sajian yang mengetengahkan aspek-aspek estetis-koreografis. Pelaksanaan ritual merupakan peristiwa budaya karena tidak hanya diwujudkan lewat salah satu materi persembahan tetapi penggabungan berbagai unsur yaitu ritual slametan atau makan bersama dengan sarana yang sudah disepakati dan dibakukan oleh seluruh warga dengan penyajian berbagai bentuk seni pertunjukan.

Sudah menjadi suatu kebiasaan bagi masyarakat agraris yang mayoritas warganya adalah petani, ungkapan yang menyatakan rasa syukur diwujudkan ke dalam sebuah upacara ritual. Dalam upacara ritual bukan sa- 
rana dan aspek yang membangun bentuk yang dikedepankan, melainkan tujuan atau maksud penyelenggaraannya yang sangat diutamakan (Soedarsono dalam Kusmayati, $2000: 41$ ).

Pelaksanaan ritual Ider Bumi, dengan menyajikan berbagai macam seni yang diwujudkan dalam sajian prosesi (arak-arakan), merupakan jalan bersama seluruh peserta dengan mengikuti rute yang telah ditentukan, dalam peristiwa ini terjadi interaksi yang sangat akrap antar semua peserta. Arak-arakan dapat disejajarkan dengan sebuah festival karena merupakan sebuah pesta budaya yang bersifat publik, yang selalu dikaitkan dengan ritus keagamaan. Adapun ciri festival adalah pluralitas ekspresi seni budaya (Hidayat, 2003:9). Ritual Ider Bumi mampu menunjukkan betapa eratnya hubungan antara agama dan budaya yang tampil di dalam sebuah festival.

Sumber yang menjelaskan tentang asal-usul ritual Ider Bumi ini tidak banyak didapat bahwa peristiwa budaya ini sudah diyakini oleh seluruh warga desa, dan penyebarannya secara lisan. Walaupun hanya ada satu data yang tersurat, mereka tetap meyakininya. Sumber tertulis yang didapat men jelaskan bahwa kira-kira sekitar tahun 1800-an, rakyat Desa Kemiren terserang pageblug (bahasa Kemiren blindeng). Apabila ada orang yang pagi sakit sorenya mati, demikian juga apabila ada yang sakit sore paginya mati. Wabah tersebut tidak hanya menyerang manusia, tetapi semua tanam-an di sawah juga diserang hama, sehingga masyarakat menjadi sangat ke-takutan dengan adanya kejadian itu. Pada malam hari mereka tidur berkelompokkelompok tidak ada yang berani tidur sendiri di rumahnya. Akhirnya ada be berapa sesepuh Desa Kemiren mendatangi (ziarah) ke makam Buyut Cili guna mendapatkan pertolongan dan petunjuk bagaimana caranya memberantas pagebluk tersebut. Selang beberapa hari mereka mendapatkan wangsit lewat mimpi bahwa masyarakat Desa Kemiren diharuskan untuk mengadakan upacara slametan dan arak-arakan yang melintasi jalan desa. Setelah masyarakat melaksanakan apa yang menjadi petunjuk dari Buyut Cili semua penyakit atau pagebluk hilang. Pengakuan seorang informan bahwa mulai saat itu ritual ini tetap dilaksanakan (Lilik Serat, brosur Upa-cara Ider Bumi, 2003 dan 2004).

Ada sebuah peristiwa yang bisa menambah keyakinannya untuk tidak meninggalkan ritual ini yaitu suatu saat di Desa Kemiren pernah tidak menyelenggarakan ritual Ider Bumi. Informan lainnya mengatakan:

"ada kejadian yang mengagetkan seluruh warga bahwa salah satu anggota keluarga pemilik Barong mendadak sakit dan kejang-kejang, bergerak dan menyeringai seperti gerakan dan wajah Barong, dan akhirnya meninggal. Dari saat itu mereka takut meninggalkan ritual ini sampai sekarang “.

Fenomena ini sesuai pendapat Smith tentang upacara Bersaji bahwa ada tiga gagasan penting mengenai azas-azas religi dan agama yaitu sistem 
upacara yang merupakan suatu perwujudan dari religi dan dalam banyak agama upacaranya tetap, tetapi latar belakang keyakinan dan maksudnya berubah. Agama atau religi mempunyai fungsi sosial untuk mengintensifkan solidaritas masyarakat, yang menganggap bahwa melakukan upacara adalah kewajiban sosial. Fungsi upacara bersaji adalah sebagai suatu aktivitas untuk mendorong rasa solidaritas dan sekaligus sebagai wujud dari upacara yang meriah tetapi keramat, bukan sebagai upacara yang kidmat dan keramat (Koentjaraningrat,1987:67-68).

Apa yang dijalani masyarakat Using adalah wujud dari religi berdasarkan keyakinannya, karena religi merupakan segala sistem tingkah laku manusia untuk mencapai suatu maksud dengan cara menyadarkan diri kepada kemauan dan kekuasaan makluk halus yang menempati alam (Koentjaraningrat,1987:54).

\section{Pelaksanaan Ritual Ider Bumi}

Meminjam konsep enkulturasi Dyson dalam Sujarwa (1999:20), ritual Ider Bumi merupakan proses ketika individu memilih nilai-nilai yang dianggap baik dan pantas bagi kehidupan bermasyarakat, sehingga dapat dipakai sebagai pedoman untuk bertindak. Konsep ini juga diwujudkan dalam keterlibatan masyarakat dalam persiapan ritual Ider Bumi

Upacara Ider Bumi dilaksanakan oleh seluruh warga Desa Kemiren, dari anak-anak sampai orang tua. Mereka ada yang terlibat langsung dalam prosesi dan ada juga sebagai peserta yang ikut meramaikan pelaksanaan upacara. Keterlibatan anak-anak tidak hanya sebagai penggembira untuk ikut meramaikan jalannya upacara, tetapi secara tidak langsung anak-anak terlibat dalam ritual ini yaitu pada saat penaburan sesaji. Pada waktu itu terlihat adanya interaksi antara yang tua, muda, dan anak-anak.

Keterlibatan warga dimulai dari persiapan upacara, diawali dari penetapan panitia penyelenggara, pemasangan umbul-umbul, spanduk dan hiasan-hiasan lainnya, juga pembuatan tempat upacara dan panggung musik tradisi ataupun Angklung Paglak. Pada tahun 2003 pelaksanaan upacara Ider Bumi juga dimeriahkan oleh pementasan musik Kendhang Kempul yang merupakan musik khas Banyuwangi. Untuk penyelenggaraan tahun 2004 kesenian tersebut tidak dipentaskan, untuk memeriahkan suasana upacara hanya dipentaskan musik tradisi dan Angklung Paglak. Di masing-masing keluarga juga tampak adanya persiapan keperluan upacara.

Pelaksanaan ritual Ider Bumi setiap setahun sekali, tepatnya hari raya Idul Fitri kedua. Dalam hal ini terjadi penggabungan antara Islam dan praIslam. Hari raya Idul Fitri merupakan hari yang disakralkan oleh umat Islam. Pada hari ini diyakini merupakan hari kemenangan atau hari yang suci karena kembalinya umat manusia ke fitrahnya. Dalam pandangan masyarakat Using yang mayoritas memeluk agama Islam, saat itu merupakan hari yang tepat untuk menyelenggarakan ritual Ider Bumi. Unsur non-Islam 
dapat dilihat adanya kepercayaan terhadap ritual di luar ajaran Islam. Dari hari pelaksanaan dan wujud ritual ini sekaligus menunjukkan bahwa Islam dalam lingkungan masyarakat Using tidak dilaksanakan secara murni, karena terdapat penggabungan antara ajaran Islam dan tradisi (sinkretisme).

Seperti dikatakan Abdalla (2002:458) bahwa sinkretisme merupakan percampuran antara Islam dengan unsur-unsur lokal Jawa. Sehingga Islam tidak lagi tampil dalam wujudnya yang asli, tetapi sudah bercampur dengan unsur-unsur yang eksternal. Maka dari itu Islam di Jawa merupakan Islam yang telah menyatukan dalam dirinya unsur-unsur lokal dan pra-Islam.

Ahimsa-Putra (2001:355) juga menjelaskan tentang sinkretisme lewat pernyataannya bahwa sinkretisme dapat dimaknai sebagai hasil dari penyelarasan, menggabungkan atau mengkombinasikan prinsip-prinsip atau praktek-praktek yang saling berlawanan. Maka dari itu sinkretisme sebagai upaya untuk mengolah, menyatukan, mengkombinasikan dan menyelaras-kan dua atau lebih sistem prinsip, sehingga terbentuk suatu prinsip baru yang berbeda dengan sebelumnya.

\section{ELEMEN-ELEMEN RITUAL IDER BUMI}

\section{Lokasi Upacara}

Pelaksanaan ritual Ider Bumi di Desa Kemiren dilaksanakan di beberapa tempat terkait persiapan upacara dan pelaksanaannya meliputi:

Persiapan penyelenggaraan upacara dilaksanakan di makam Buyut Cili, merupakan tempat yang disakralkan bagi masyarakat Desa Kemiren. Di tempat inilah bersemayam danyang desa, yang diyakini mempunyai kekuatan magis. Selain di makam Buyut Cili, ritual juga dilaksanakan di rumah Barong (rumah Safii tempat tersimpannya perlengkapan Barong). Ritual ini dilaksanakan sebagai permohonan ijin untuk melaksanakan upacara Ider Bumi dan dimaksudkan agar pelaksanaan upacara berjalan lancar, mendapatkan keselamatan baik pemilik Barong maupun masyarakat seluruh Desa Kemiren.

Fenomena ini seperti dikatakan Tylor bahwa jiwa yang telah terlepas dari jasmaninya akan mampu berbuat sekehendaknya, dan yang memenuhi alam semesta disebutnya dengan spirit. Dengan demikian dalam pikiran manusia mentransformasikan kesadaran akan adanya jiwa menjadi keyakinan kepada makluk-makluk halus, diberikan tempat yang sangat penting dalam kehidupannya, kemudian menjadi objek penghormatan dan penyembahan yang disertai dengan berbagai upacara (Koentjaraningrat, $1987: 49$ ).

Tempat sentral dari pelaksanaan upacara Ider Bumi dapat dibagi menjadi dua tempat. Prosesi arak-arakan diselenggarakan di sepanjang jalan utama desa, yaitu dari ujung timur (perbatasan dengan Desa Banjarsari) sampai ujung barat (perbatasan dengan Desa Tamansuruh). Sebagai tempat puncak acara ritual adalah di jalan desa, dimulai (sebagai batas paling timur) dari 
depan rumah Barong memanjang ke barat sepanjang diperlukan. Artinya pengikut ritual Ider Bumi tidak dibatasi yang mengakibatkan tempat slametan (makan bersama) juga tidak bisa dibatasi. Penyelenggaraan ritual Ider Bumi tidak menggunakan tempat lain walaupun misalnya terjadi hujan. Pelaksanaan ritual yang dimulai dari timur menuju ke barat hal ini juga dikaitkan dengan keyakinan yang dianut yaitu Islam, bahwa sebagai kiblatnya arah barat. Dengan demikian tampak dengan jelas bahwa segala aktivitas masyarakat Using di Desa Kemiren selalu terdapat penggabungan antara agama yang dianut dengan warisan budaya yang masih dijalani.

\section{Sarana upacara}

Sesaji merupakan salah satu sarana upacara yang tidak bisa ditinggalkan, dan disebut juga dengan sesajen yang dihaturkan pada saat-saat tertentu dalam rangka kepercayaan terhadap makluk halus, yang berada di tempat-tempat tertentu. Sesajen merupakan jamuan dari berbagai macam sarana seperti bunga, kemenyan, uang recehan, makanan, yang dimaksudkan agar roh-roh tidak mengganggu dan mendapatkan keselamatan (Koentjaraningrat dkk, $2002: 349$ ).

Perlengkapan sesaji biasanya sudah menjadi kesepakatan bersama yang tidak boleh ditinggalkan karena sesaji merupakan sarana pokok dalam sebuah ritual. Adapun sesaji dalam ritual Ider Bumi dapat dikelompokkan menjadi tiga karena rentetan upacara terkait dengan tiga tempat, yaitu ritual di makam Buyut Cili, di rumah Barong dan di jalan desa. Sesaji untuk upacara di makam Buyut Cili terdiri dari :

1. Tumpeng terbuat dari nasi putih berbentuk kerucut yang menyerupai gunungan dimaksudkan untuk memberi sedekah dan sekaligus menghormati para dewa dan ruh-ruh yang bersemayam di gunung.

2. Pecel pitik yaitu ayam panggang dicampur dengan bumbu pecel (Using) terbuat dari parutan kelapa atau disebut dengan bumbu urap (Jawa).

3. Jenang abang (merah) dan putih yaitu bubur yang terbuat dari beras. Untuk jenang abang dicampur dengan gula kelapa.

4. Dua batang rokok.

5. Kinangan yang terdiri dari daun sirih, gambir, tembakau, enjet (kapur).

6. Toya arum yaitu air yang diisi dengan bunga berbau harum terdiri dari bunga Kenanga dalam bahasa Using disebut dengan bunga Wangsa, bunga Cempaka disebut dengan bunga Pecari, bunga Sedapmalam dan boleh juga ditambah dengan bunga Mawar.

7. Sekul arum atau kemenyan dengan cara dibakar untuk mendapatkan aroma dan asapnya, sekaligus sebagai penambah suasana sakral.

Sesaji yang dipergunakan di rumah Barong tidak seperti yang diperlukan di tempat lainnya, karena di tempat itu hanya dilaksanakan ritual kecil sebagai wujud permintaan ijin untuk melaksanakan ritual Ider Bumi. Upaca ra kecil di rumah Barong dilaksanakan sebelum dimulai kegiatan persiapan 
untuk menata keperluan arak-arakan, dari pemasangan pernak-pernik Barong, pemakaian pitik-pitikan dan macan-macanan, dan menata gamelan yang diperlukan. Menurut kepercayaan mereka setelah pelaksanaan ritual di makam Buyut Cili, Barong tersebut sudah dimasuki danyang desa tersebut, maka pendukung yang terlibat tidak berani memegang Barong, yang diperbolehkan dan berani hanya pemiliknya. Sesaji yang diperlukan adalah sekul arum dan rokok.

Sesaji yang digunakan di jalan desa yaitu pada waktu arak-arakan Barong terdiri dari :

1. Sekul arum (kemenyan) yang dibakar.

2. Toya arum.

3. Jenang abang dan jenang putih.

4. Sembur utik-utik, sesaji yang ditaburkan saat arak-arakan. Terdiri dari beras yang diberi warna kuning, dicampur dengan uang receh yang berjumlah harus ganjil. Biasanya berjumlah Rp 99.000.-. Uang ini dari tahun ketahun biasanya disumbang oleh salah satu warga pendatang yang sudah lama menetap di Kemiren, dan berisi bunga kenanga.

5. Sego golong yaitu nasi putih yang dibungkus dengan daun pisang dan di tengahnya berisi telur rebus.

6. Tumpeng.

7. Pecel pitik jumlah dan ukuran (besar dan kecilnya) pecel pitik dan tumpeng tidak ada ketentuan tergantung siapa yang mempunyai kemauan.

\section{Prosesi Ider Bumi}

Sajian Ritual Ider bumi berupa prosesi arak-arakan yang dilaksanakan pada siang hari sekitar jam 15.00 (setelah sembahyang dhuhur menginjak asyar) dengan pertimbangan saat itu cuaca tidak terlalu panas, dan pelaksanaan upacara memakan waktu yang relatif lama, maka diharapkan upacara selesai tidak terlalu malam. Pelaksanaan ritual Ider Bumi didukung oleh beberapa elemen, yang dilaksanakan dengan berurutan. Struktur sajiannya tidak ada pembakuan karena berdasarkan pelaksanaan tahun 2003 dan 2004 terdapat perbedaan. Adapun urutan peserta arak-arakan adalah sebagai berikut.

1. Paling depan dua orang pembawa umbul-umbul khas Kemiren, yang berjalan beriringan sebelah kanan dan kiri. Umbul-umbul khas Kemiren yaitu terbuat dari pelepah pohon enau yang masih disisakan sedikit daunnya, dan diisi (gantungan) kain motif juono (rembang) dan bermacam jajan. Pembawa umbul-umbul memakai pakaian tulik yaitu busana putra khas Banyuwangi.

2. Pendukung utama ritual Ider Bumi yaitu sekelompok kesenian Barong yang diawali dengan sepasang penari macan-macanan. Posisi mereka juga beriringan di sebelah kanan dan kiri. Selama prosesi penari macanmacanan tampak hanya berjalan biasa (tidak mengadakan atraksi). Di belakangnya sepasang pitik-pitikan (ayam-ayaman), dengan posisi beriringan sebelah kanan dan kiri. Keduanya sering kali terlihat mengekspresikan 
Ritual Ider Bumi di Desa Kemiren ... (Sulistyani)

gerakan menari dengan berjalan. Kemudian dibelakangnya lagi adalah peran utama yaitu penampilan Barong dengan menari sambil berjalan, dilanjutkan kelompok musik.

3. Modin yaitu aparat desa di bidang urusan agama dengan menaburkan sesaji (sembur utik-utik) yang didampingi pemangku adat. Pada bagian ini yang tampak paling ramai diantara para seserta karena selalu diikuti oleh anak-anak untuk merebutkan taburan sesaji berisi uang, yang ditaburkan modin. Mereka saling berebut untuk mendapatkan sesari (uang recehan).

4. Kelompok ibu-ibu dengan membawa sesaji (sembur utik-utik), kinangan dan air yang dimasukkan ke dalam kendhi, masing-masing dibawa dengan ditempatkan di dalam bokor kuningan dan dibawa dengan digendong memakai kain khas Using Kemiren yang dipakai hanya pada upacara-upacara ritual.

5. Kelompok Jebeng-tulik yaitu kelompok muda-mudi Using dengan busana khas Banyuwangi. Jebeng membawa sesaji (jenang beras warna merah dan putih dengan dilengkapi air), sedangkan tulik mendampingi dengan membawa payung untuk menghindari sinar matahari.

6. Kelompok pembawa tumpeng yang diusung dengan ancak.

7. Kelompok jaran kecak, dinaiki oleh Bupati Banyuwangi dan Kepala Dinas Pariwisata Seni dan Budaya, atau yang mewakili serta diikuti penunggang kuda lainnya yaitu seorang anak kecil. Jaran kecak adalah seekor kuda yang berjalan dengan menggerak-gerakan kepala dan langkah kaki mengikuti irama musik.

8. Di belakangnya adalah kelompok musik rebana (bordah) dengan memakai busana muslim.

9. Berikutnya kelompok ibu-ibu PKK dengan berbusana adat.

10. Diikuiti kelompok aparat desa yaitu kepala desa dan staf, serta masyarakat yang melibatkan diri dalam prosesi dengan berbusana khas Using. Mereka memakai baju dan celana warna hitam, dengan udeng (destar) dan kain batik motif gajah uling.

11. Diikuti kelompok musik Kuntulan, sajian dari musik tersebut mampu memeriahkan suasana karena kompak dan bunyi yang dihasilkan sangat keras. Diantara sekian musik yang mengikuti prosesi hanya musik Kuntulan yang kelihatan dominan.

12. Terakhir adalah kelompok masyarakat yang mengikuti perjalanan ritual ini, sebagai penggembira dan menambah maraknya suasana.

Prosesi diawali dengan mengatur urutan peserta, dimulai dari rumah Barong melintasi jalan utama desa dan terakhir dipusatkan ditempat pelaksanaaan slametan. Setelah rombongan arak-arakan sampai di tempat yang sudah ditentukan, disambut oleh warga yang tidak mengikuti arak-arakan dengan menggelar tikar atau alas duduk lainnya dan menyiapkan sarana slametan, diawali dengan pembacaan doa, yang menggunakan bahasa Using dan dilanjutkan dengan bahasa Arab, sebagai pernyataan niat diselenggarakan slametan dan dilanjutkan makan bersama. Dalam acara slametan tampak suasana kerakraban seluruh warga yang tidak mengenal status sosial ataupun 
umur, mereka bersama-sama mengadakan ritual untuk kebutuhan bersama.dari tahun ketahun tampaknya urutan prosesi tidak selalu sama,

Penyelenggaraan upacara ritual Ider Bumi dalam sajiannya terjadi pergeseran. tergantung panitia pelaksana, salah satu contoh pelaksanaan tahun 2003 dan 2004 ada perbedaan. Pada tahun 2003 dilibatkannya musik Angklung Paglak ke dalam prosesi upacara arak-arakan, sedangkan tahun 2004 musik Angklung Paglak hanya dimainkan di tempat (pusat acara) sebagai pengisi waktu, Juga tahun 2004 sudah mulai ada penambahan pe-serta prosesi yang ditata apik sebagai sebuah kemasan, misalnya pada tahun 2003 tidak ada peserta muda-mudi (jebeng tulik) dengan memakai busana khas Banyuwangi. Tahun 2004 dimasukkannya kelompok ini dengan warna busana seperti kebutuhan panggung, apalagi dengan menampilkan seorang wisatawan dari luar negeri. Akibat dari keterlibatannya menjadi pusat perhatian dari penonton.

Selain itu dahulu sarana upacara (sesaji) yang berupa tumpeng dan perlengkapan sarana slametan tidak diikutkan dalam prosesi. Kemudian dalam pelaksanaan ritual tahun 2004 perlengkapan tersebut dimasukkan ke dalam prosesi ritual dengan tumpeng ukuran besar yang ditata dalam tempat ancak, diusung oleh empat orang warga yang berbusana seragam. Menurut keterangan informan pergeseran ini dimaksudkan agar sajian prosesi ritual Ider Bumi lebih menarik. Dengan penataan yang lebih menonjolkan segi artistik ini, sesungguhnya mempunyai dampak terhadap kesakralan ritual Ider Bumi, karena ritual ini menjadi semacam sebuah penampilan karnaval atau sebuah atraksi budaya.

Adanya pergeseran dalam pelaksanaan ritual Ider Bumi ini merupakan fenomena baru dalam sebuah atraksi budaya seperti dijelaskan bahwa kecenderungan kapitalis konsumen global masa kini adalah ketiadaan batas kebutuhan/keinginan, dimana celah pasar, standardisasi, dan kenikmatan da ri transformasi identitas secara konstan menimbulkan heterogenitas.(Ang, 1996 dalam Barker, 2004:120 dan 2005:157)

Dengan adanya penataan terhadap prosesi ritual mempunyai dampak bahwa kesakralan bukan menjadi prioritas utama, melainkan yang lebih diutamakan adalah sebuah kemasan yang bagus dan mampu menjadi daya tarik. Hal ini sejalan dengan kosep glokalisasi yang dijelaskan oleh Robetson dalam Barker (2004:120 dan 2005:157) bahwa glokalisasi berakar dari istilah pemasaran, untuk mengekspresikan produksi lokal secara global dan lokalisasi global.

Turut campurnya Pemerintah Daerah terhadap pelaksanaan upacara ini sesungguhnya menempatkan posisi sesepuh desa dan aparat desa termarjinalkan, karena mereka tidak diberikan kewenangan dalam menentukan waktu pelaksanaan ritual Ider Bumi. Ketidak kuasaan sesepuh/aparat desa dalam pelaksanaan Ritual Ider Bumi ini dan adanya niat untuk menambah daya tarik penonton lebih tepat jika peristiwa ini dikategorikan dalam hege- 
moni karena pada prinsipnya seperti disampaikan Gramsci bahwa hegemoni merupakan supremasi suatu kelompok sosial yang menyatakan dirinya dalam dua cara yaitu sebagai dominasi dan sebagai kepemimpinan moral dan intelektual. Adanya dominasi suatu kelompok terhadap kelompok yang lain karena dalam hegemoni bersifat ekonomik dan etis-politis, dan aktivitas ekonomik merupakan prinsip pertama yang harus diperhitungkan (Faruk, 1999:68).

Penjelasan hegemoni Gramsci juga diperkuat oleh pernyataan da-lam Srinati (2003:189) bahwa konsep hegemoni adalah sebuah politik yang telah berhasil membujuk kelas-kelas lain dan masyarakat untuk menerima nilai-nilai moral, politik, maupun kultural. Jika kelas penguasa berhasil maka kelas ini akan menggunakan kekuatan sedikit mungkin. Tetapi kepemimpinan merupakan hal yang sangat krusial dalam hegemoni.

\section{SIMPULAN}

Ritual Ider Bumi merupakan salah satu wujud upacara ritual yang masih dijalani oleh masyarakat Using di Desa Kemiren. Merupakan warisan budaya yang tetap diyakini walaupun keyakinan yang dianut saat ini tidak mengajarkan adanya percaya atau keyakinan terhadap suatu benda atau makam. Tetapi masyarakat Using di Desa Kemiren mampu menggabungkan keduanya dengan tidak mempertentangkan, walaupun menumbuhkan berbagai sinkretisme.

Sinkretisme merupakan percampuran antara Islam dengan unsurunsur lokal, sehingga Islam tidak lagi tampil dalam wujudnya yang asli, tetapi sudah bercampur dengan unsur-unsur yang eksternal, maka dari itu Islam di Desa Kemiren (yang dilaksanakan oleh masyarakat Using) merupakan Islam yang telah menyatukan dalam dirinya unsur-unsur lokal dan non-Islam. Dengan sinkretisme mampu menjadikan masyarakat Using memiliki kekayaan budaya yang barangkali tidak didapatkan di tempat lain.

Sebagai salah satu contoh sinkretisme yang diyakini dapat dilihat saat pelaksanaan upacara ritual Ider Bumi yaitu pelaksanaannya tepat pada hari raya Idul Fitri yang merupakan hari yang diyakini oleh masyarakat Islam sebagai hari yang suci dan penuh berkah di satu sisi ritual Ider Bumi sangat terkait dengan kepercayaan terhadap kekuatan suatu benda. Begitu pula doa yang digunakan dalam ritual Ider Bumi adalah ayat-ayat dalam agama Islam, juga sarana sesaji yang harus dipersiapkan yang berupa kemenyan, bunga dan lainnya.

Dengan perpaduan antara ajaran agama yang diyakini dan kepercayaan lain mampu memperkaya berbagai ragam budaya yang lahir di tengah-tengah masyaarakat Using, khususnya di Desa Kemiren. 
Ritual Ider Bumi di Desa Kemiren ... (Sulistyani)

\section{DAFTAR RUJUAKAN}

Abdalla, Ulil Abshar. 2002. "Serat Centhini, Sinkretisme Islam, dan Dunia Orang Jawa dalam Bentara esei-esei. Jakarta: Buku Kompas.

Ahimsa-Putra, Heddy Shri. 2000. Ketika Orang Jawa Nyeni. Yogyakarta: Galang Press.

Barker, Chris. 2004. Cultural Studies. Teori dan Praktik. Yogyakarta: Kreasi Wacana.

Daeng, Hans J. 2000. Manusia, Kebudayan dan Lingkungan Tinjauan Antropologis. Yogyakarta : Pustaka Pelajar.

Endraswara, Suwardi. 2003. Falsafah Hidup Jawa. Tangerang: Cakrawala. 2003. Metodologi Penelitian Kebudayaan. Yogyakarta: Gajah Mada University Press.

Faruk. 1999. Pengantar Sosiologi Sastra dari Strukutralisme Genetik sampai PostModernisme. Yogyakarta: Pustaka Pelajar.

Hidayat, Komaruddin. 2003. Budaya Lokal dalam Perspektif Baru Dialektika Agama dan Budaya dalam Sinergi Agama \& Budaya Lokal. Surakarta: UNMU Press.

Koentjaranigrat. 1987. Sejarah Teori Antropologi I. Jakarta : Universitas Indonesia (UI Press).

2002. Kebudayaan Mentalitas Dan Pembangunan (Bunga Rampai). Jakarta: PT Gramedia Pustaka Utama.

Kusmayati, A.M. Hermin. 2000. Arak-Arakan Seni Pertunjukan dalam Upacara Tradisional di Madura. Yogyakarta: yayasan Untuk Indonesia.

Lilik Serat. 2003. Brosur Upacara Ider Bumi di Desa Kemiren.

Poerwadarminta, WJS. 1939. Baoesastra Djawa. Batavia: JB. Wolters Uitgevers. .1976. Kamus Umum Indonesia. Jakarta: PN. Balai Pustaka.

Soedarsono, R.M. 1998. Seni Pertunjukan Indonesia di Era Globalisasi. Cetakan kedua Jakarta: Direktorat Jendral Pendidikan Tinggi Departemen Pendidikan dan Kebudayaan.

2002. Seni Pertunjukan Indonesia Di Era Globalisasi. Yogyakarta: Gajah Mada University Press.

Srinati, Dominic. 2003. Popular Cultural Pengantar Menuju Teori Budaya Populer. Yogyakarta: Bentang Budaya.

Sujarwa. 1999. Manusia dan Fenomena Budaya Menuju Perspektif Moralitas Agama. Yogyakarta: U. Ahmad Dahlan dengan Pustaka Pelajar. 